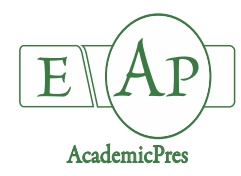

Onody E et al. $(2020)$
Notulae Botanicae Horti Agrobotanici Cluj-Napoca 48(2):1027-1042
DOI: $10.15835 /$ nbha48211856
Research Article

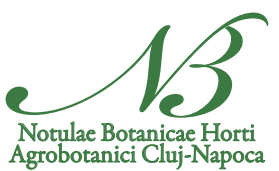

\title{
Water use estimation and growth of container grown tatarian dogwood (Cornus alba L. 'Sibirica') and cherry laurel (Prunus laurocerasus L. 'Novita')
}

\section{Éva ÓNODY ${ }^{1 *}$, Magdolna SÜTÖRINÉ DIÓSZEGI², Károly HROTKÓ²}

\author{
${ }^{1}$ Szent István University, Faculty of Horticultural Science, Department of Medicinal and Aromatic Plants, Villanyi 29-43, H-1118 \\ Budapest, Hungary; eva.onody@gmail.com (*orresponding author) \\ ${ }^{2}$ Szent István University, Faculty of Horticultural Science, Department of Floriculture and Dendrology, Villányi 29-43, H-1118 \\ Budapest, Hungary; Hrotko.Karoly@kertk.szie.hu; Dioszegi.Magdolna@kertk.szie.hu
}

\begin{abstract}
The pot in pot (PIP) system is a new alternative to container above ground (CAG) cultivation in nurseries. Our study estimates plant water usage of plants in CAG and PIP. Plant species, nursery container type and year effect on morphological parameters (plant size, leaf area, fresh and dry weight), on daily water use (weighed DWU), transpiration of leaves (DT) supplemented with species effect were analysed. Twenty plants grown in $5 \mathrm{~L}$ plastic pots of each combination were investigated. For leaf area measurement by AM350 we sampled 30 leaves from each plant. Forty plants were weighed by a digital scale morning and evening on each sampling day. Leaf gas exchange was measured on the same days by using leaf gas exchange analyser. From the two investigated deciduous (tatarian dogwood) and evergreen species (cherry laurel), only the tatarian dogwood showed improved quality in the PIP system (enhanced canopy increment, fresh and dry weight). Significant difference showed the two species in DWU, and in DT. The tatarian dogwood used $626 \mathrm{~g} \mathrm{day}^{-1}$ water (194\%) compared to the cherry laurel's $341 \mathrm{~g}$ day $^{-1}$ water use and this ratio was $144 \%$ in favor of tatarian dogwood in the next year. We measured higher initial morning weight (IWC) in PIP system. The transpiration measurements on single selected leaves overestimated the real transpiration compared to DWU. The DT of the deciduous tatarian dogwood responses more sensitively to environmental conditions than the evergreen cherry laurel.
\end{abstract}

Keywords: container production; daily water use; leaf area; pot in pot; transpiration

\section{Introduction}

Reports and calculations estimate that agriculture actually consumes $50-60 \%$ of the total water use of humanity. Majority of that amount used for irrigation on agricultural crops. Hence, it is essential to have economic and effective water usage, reasonable planned irrigation management for providing suitable crop. Nursery products in the USA were grown around 70\% in container (Majsztrik et al., 2011), this rate of container grown ornamental plants in Hungary is around 50\% (MDSZ, 2014). Thus, for planning and 
irrigation management a crucial step is to know the precise amount of water demanded by the different container grown ornamentals.

The water management and advanced irrigation technology of container grown woody ornamental plants reviewed by Majsztrik et al. (2017). There are few literature data on water use of container grown woody ornamentals (Beeson, 2004; 2005; 2006; Beeson and Chen, 2018), which may contribute to more precise planning and irrigation management. Most of the methods to calculate water use of container plants, especially for woody ornamentals, have high inaccuracy. The crop coefficients related to area unit are calculated to the total crop but not for individual plants. Most of water use studies focused on the determination of crop coefficient for woody ornamentals grown in container (Niu et al., 2006; Grant et al., 2010); however, understanding factual values of container grown plants water use, would need a more practical approach.

There are papers dealing with the effects of containers above ground on water use, rather than the effects of pot in pot on water use. The "pot in pot" (PIP) system is a special type of nursery container production system. The system consists of a holder pot sunk below the ground level and a containerized plant placed into the holder pot for the production period. The system has been proven to reduce the temperature of the root zone (substrate temperature) (Newman, 2014). During the production of conventional above ground container $(\mathrm{CAG})$, the container exposed to the solar radiation, thereby raising the temperature of the substrate, which can cause damage on the plant root system. Temperature above of the optimal root zone temperature, reduces the dry matter accumulation in plant parts and effects on the shoot and root morphology of the temperature sensitive species. In PIP, the root zone temperature fluctuates less than the air temperature due to the soil's insulating effect. There are variations in root membrane thermostability by species (Ingram $e t$ al., 2015). Previous studies have shown that the PIP-grown plants produced higher biomass and dry matter content, especially in roots (Schluckebier and Martin, 1997; Martin et al., 1999), by comparison of the conventional above ground container. However, it was not always statistically proven, moreover, the conventional container type showed improved morphology and higher yield in some cases (Miralles et al., 2009). The fertilizer rate study conducted to PIP have been shown, that higher nutrient charge remained in the substrate of PIP than CAG after 10 months, also due to the lower medium temperature, and the higher biomass product (Ruter, 1998a).

According to the research on PIP water use so far show, that the evapotranspiration rate of CAG and PIP is different (Ruter, 1998b) which is influenced by three factors, lower soil matrix potential in CAG compared to PIP, higher biomass product in PIP and the effect of the climatic conditions (Miralles et al., 2009; 2012; 2016).

Regarding the influence of container type on water use and plant growth of container production, there has been no research done in Hungarian nurseries; further on there are no studies carried out in association with PIP production systems. Our research work is based on the fact, the wide assortment of woody ornamentals in nurseries, are grouped by size and water demand, regarding irrigation management. Two popular ornamental plant varieties were investigated. The purpose of our study, to estimate the water use of two commonly produced ornamental shrubs, such as the fast growing deciduous tatarian dogwood (Cornus alba L. 'Sibirica') and the fast-growing evergreen cherry laurel (Prunus laurocerasus L. 'Novita'). According to literature data, they have same water demand and growth rate (Tóth, 2012). Further on we evaluate the effect of production systems (further on "container types”) as pot in pot (PIP) and conventional above ground container (CAG) as well as study the effect of years with different weather conditions on plant growth and water use of plants. 


\section{Materials and Methods}

\section{Tested plants}

As test plant material we used tatarian dogwood (Cornus alba L.) 'Sibirica' and cherry laurel (Prunus laurocerasus L.) 'Novita' rooted cuttings. The individuals were selected randomly (20 pieces per species) from the nursery's stock, where each species was grown under the same condition. The plants were transplanted to black plastic pots of $5 \mathrm{~L}$ volume, $23 \mathrm{~cm}$ upper diameter and $18 \mathrm{~cm}$ height (Interplast Plastic Products, Poland). The pots were filled with white peat (100\%) (Pindstrup Substrate, Latvia) and 3.5-4.5 $\mathrm{g} \mathrm{L}^{-1}$ controlled release fertilizer $(11 \mathrm{~N}+10 \mathrm{P}+19 \mathrm{~K}+2 \mathrm{MgO}+$ trace elements (TE), Osmocote Pro, 8-9 M) have been added to white peat.

\section{Production methods (container types)}

Two container types were set up. The pot in pot (PIP) system consists of placing cultivation pot in pot below ground level. The buried pots are same type of used to transplanted plants. Containers above the ground (CAG) level refer to the conventional container production.

\section{Experiment set up}

The experiment was carried out in an assigned plot of an operating pot in pot production field, in the Jaroslaw Chabin Ornamental Tree Nursery in Páty, Hungary ( $\left.47^{\circ} 31^{\prime} 1^{\prime \prime} \mathrm{N}, 18^{\circ} 48^{\prime} 27^{\prime \prime} \mathrm{E}\right)$. The experimental design is shown by Figure 1.

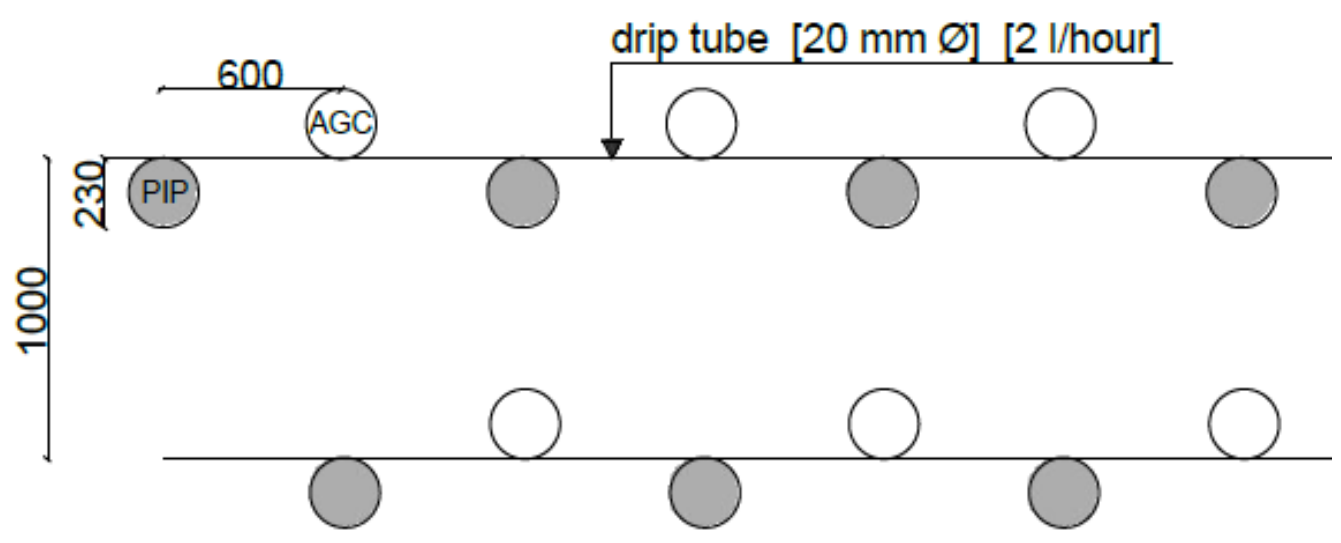

Figure 1. Experimental design (PIP - pot in pot, AGC - above ground container $(\mathrm{mm})$ )

The planting of one-year old rooted cuttings performed on 01 April 2015 and on 07 April 2016 respectively; the experiment terminated on 26 October in 2015 and 18 October in 2016. Drip irrigation system was set up with one dripper per plant $\left(2 \mathrm{~L} \mathrm{~h}^{-1}\right)$. One spaghetti tube connected to each plant. Local water source was used with parameters: $\mathrm{pH} 7.1, \mathrm{EC} 0.9 \mathrm{mS} \mathrm{cm}^{-1}$. All plants (CAG and PIP) were irrigated with the same frequency and volume of water. Irrigation frequency was changed according to season, two times per day (0800 HR and $1800 \mathrm{HR}$ ) in spring and autumn and three times per day from June to August (0800 HR; 1200 $\mathrm{HR}$ and $1800 \mathrm{HR})$. The volume of daily water was set up to $0.2 \mathrm{~L} \mathrm{pot}^{-1}$ in each case (Chabin, 2015).

\section{Measurements of morphological parameters and dry matter content}

All plant height, canopy size (the two widest points were averaged) and caliper diameter was measured at the beginning of production and the end of the experiment for both species, in each year. The difference 
between the two measurement times in a year, is shown in the study, as plant height growth, canopy - and caliper increment. For the determination of fresh and dry weight, 5-5 plants were selected randomly, per container type and species, respectively. Each plant was dismantled. Samples of each plant part (root, shoot, leaf) were collected and weighed separately and then delivered to the Laboratory of Department of Floriculture and Dendrology, Szent István University, Budapest. Samples were dried in a heating owen with gravity convection (BINDER ED 53) at $105^{\circ} \mathrm{C}$, until a constant dry mass was obtained and then reweighed. The leaf parameter as individual leaf area was measured by Area Meter (AM350, ADC BioScientific Ltd.) sampled 30 leaves from each plant. Totally, 600 leaves were scanned and then averaged by species and container type. Total leaf area was calculated as average of individual leaf area multiplied by total leaf number of a plant (5-5 plants were selected per container type and species, respectively).

\section{Gravimetric measurements (daily weight loss of a container)}

Fourty plants were weighed by a digital scale (dyras, KSCL-300), two times on each sampling day. There was no irrigation and precipitation on sampling days. The procedure was the following: in the night, before the test day, pots were irrigated as scheduled in the nursery. The next morning at $0800 \mathrm{HR}$, pots with plants were weighed to resolution of $1 \mathrm{~g}$ (it gave the data of initial morning weight of container, further on IWC), and then weighed again at evening $2000 \mathrm{HR}$. The difference between the two data provided daily water use of plant (DWU). Such sampling we carried out on 3-3 days in each year. The 6 sampling days were performed on the following dates: 05 and 30 June, 22 September in 2015 and 07 June, 05 July and 16 September in 2016.

\section{Gas exchange measurements}

Leaf gas exchange was measured on the same six dates as the gravimetric measurements were carried out in the 2015 and 2016 using a portable gas leaf gas exchange system (LCi, ADC Scientific Ltd.). Transpiration rate (E) and stomatal conductance (gs) were assessed on all plants in two hours intervals between $1000 \mathrm{HR}$ and $1600 \mathrm{HR}$ on summer days (05 and 30 June in 2015; 07 June and 05 July in 2016) and between $0900 \mathrm{HR}$ and 1500 HR on autumn days (22 September in 2015 and 16 September in 2016). Gas exchange was measured always on clear days.

The total daily transpiration (DT) value was calculated from four measurement occasion per day and 20 leaf samples per species. The instantaneous transpiration rate $\left(\mathrm{mmol} \mathrm{m}^{-2} \mathrm{~s}^{-1}\right)$ was measured on a sunlit leaf. This value was referenced to a 2 -hour time interval and then multiplied by the molar mass of water.

\section{Weather conditions}

Data on weather condition were taken from a meteorological station (imetos ${ }^{\circ}$ ) located $3 \mathrm{~km}$ from the experimental plot (Nr. 1, Petofi Sandor str., Telki, Hungary). Two years of daily temperature data, precipitation, wind speed, relative air humidity, solar radiation, daily reference evapotranspiration $\left(\mathrm{ET}_{0}\right)$ were obtained.

\section{Annual weather conditions}

The weather conditions as precipitation, potential evapotranspiration and average temperature data for 2015 and 2016 are shown in the Figure 2.

Based on the data provided by the regional weather station data were as follows: the annual total precipitation was $569.20 \mathrm{~mm}$ in 2015. Total evapotranspiration of the year was $679.90 \mathrm{~mm}$. The average annual air temperature was $11.90^{\circ} \mathrm{C}$. During the production period (from 01 April to 26 October), the total precipitation was $411.60 \mathrm{~mm}$, while the potential evapotranspiration was $586.30 \mathrm{~mm}$. The average air temperature was $17.77^{\circ} \mathrm{C}$. The annual total precipitation was $843.20 \mathrm{~mm}$ in 2016. Total evapotranspiration of the year was $651.60 \mathrm{~mm}$ and the average annual air temperature was $11.19^{\circ} \mathrm{C}$. During the production period (from 07 April to 18 October), the total precipitation was $521.80 \mathrm{~mm}$, while the potential evapotranspiration was $543.20 \mathrm{~mm}$. This time, the average air temperature was $17.61^{\circ} \mathrm{C}$. 


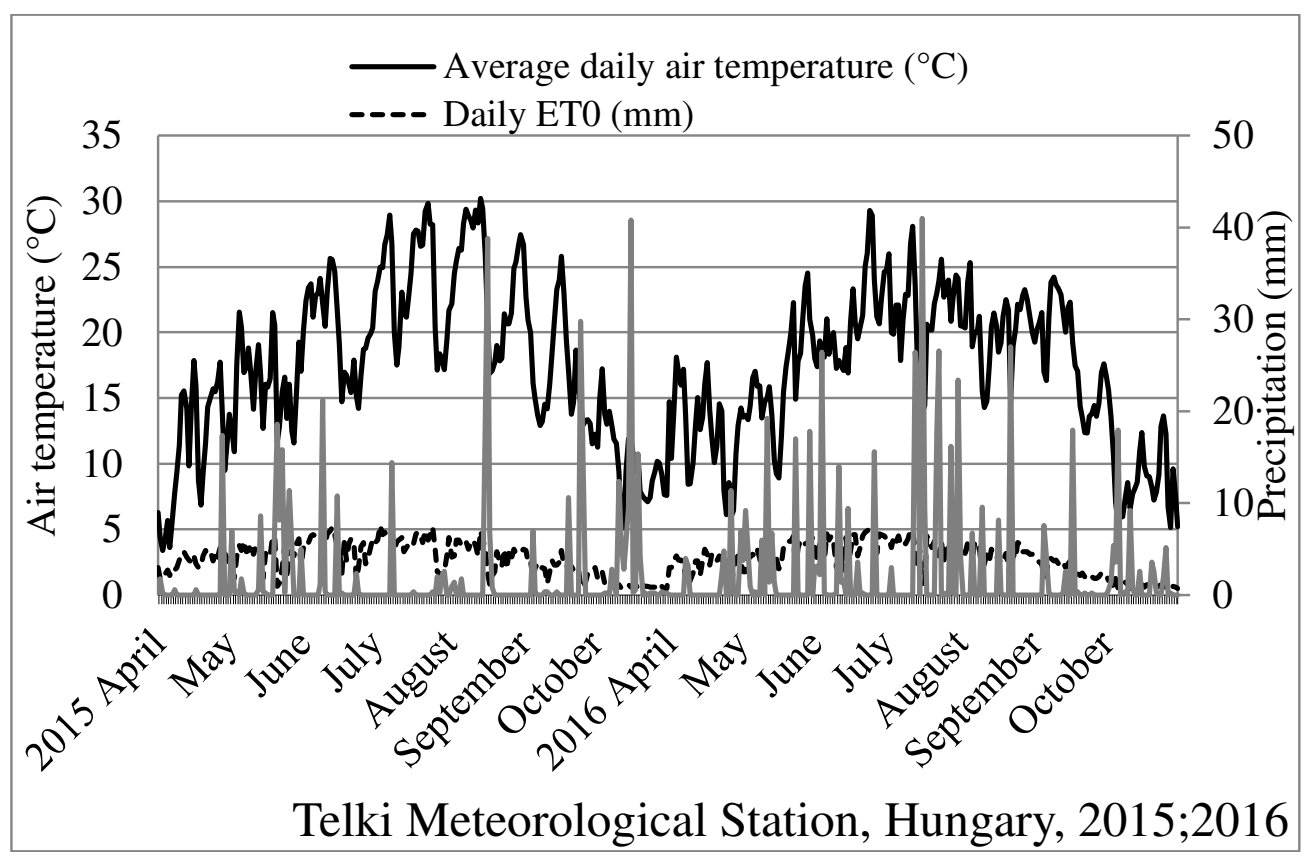

Figure 1. Annual patterns of some weather conditions in 2015 and in 2016 (imetos meteorological station, Telki, Hungary)

Weather conditions of the sampling days

The weather conditions of the sampling days shown in Table 1.

Table 1. The weather conditions of the sampling days in 2015 and in 2016

\begin{tabular}{|c|c|c|c|c|c|c|c|c|c|}
\hline Date & $\begin{array}{c}\text { Production } \\
\text { day }\end{array}$ & $\begin{array}{c}\text { Min. } \\
\mathrm{T} \\
{ }^{\circ} \mathrm{C}\end{array}$ & $\begin{array}{c}\text { Max. } \\
\mathrm{T} \\
{ }^{\circ} \mathrm{C}\end{array}$ & $\begin{array}{c}\text { Avg. } \\
\mathrm{T} \\
{ }^{\circ} \mathrm{C}\end{array}$ & $\begin{array}{c}\text { Solar } \\
\text { radiation } \\
\mathrm{W} \mathrm{m}^{-2}\end{array}$ & $\begin{array}{c}\text { Relative air } \\
\text { humidity } \%\end{array}$ & $\begin{array}{c}\text { Precipit } \\
\text { ation } \\
\mathrm{mm}\end{array}$ & $\begin{array}{c}\text { Wind } \\
\text { speed m } \\
\text { sec }^{-1}\end{array}$ & $\begin{array}{c}\mathrm{ET}_{0} \\
\mathrm{~mm}\end{array}$ \\
\hline 05062015 & 66 & 12.78 & 28.20 & 21.17 & 307 & 50.42 & 0 & 0.4 & 4.6 \\
\hline 30062015 & 91 & 11.49 & 29.13 & 20.35 & 294 & 56.29 & 0 & 0.4 & 4.3 \\
\hline 22092015 & 175 & 6.68 & 22.00 & 14.67 & 179 & 59.54 & 0 & 0.3 & 1.9 \\
\hline 07062016 & 62 & 11.37 & 24.88 & 18.33 & 310 & 47.67 & 0 & 0.3 & 4.2 \\
\hline 05072016 & 90 & 13.03 & 30.79 & 22.11 & 264 & 52.94 & 0 & 0.2 & 4.0 \\
\hline 16092016 & 163 & 18.03 & 28.63 & 22.31 & 175 & 67.51 & 0 & 0.4 & 2.6 \\
\hline
\end{tabular}

Note: $\mathrm{ET}_{0}$ - daily reference evapotranspiration

\section{Statistical analysis}

SPSS version 23 software package was used to analyse the data (IBM SPSS Statistics). ANOVA was conducted to explore the impact of the species, the nursery container type and the year effect (as independent variables) on the morphological parameters (plant height, canopy increment and caliper increment) and to describe individual and total leaf area, as well as the fresh and dry weight of the plant parts (root, shoot, leaf and total). In the above analysis the interaction of the independent variables was examined, as well.

The same method was used to evaluate the effect of the species, the nursery container type and the year effect as independent variables, on the daily water use (DWU), on the initial morning weight of container (IWC) and on the total daily transpiration (DT). Normality of the residuals was proven by KolmogorovSmirnov or Shapiro-Wilk test $(\mathrm{p}>0.05)$. Homogeneity of variances was checked by Levene's test $(\mathrm{p}>0.05)$. Finally, the DWU; IWC and DT values of each sampling days were separated by Tukey's post hoc tests $(\mathrm{p}<$ $0.05)$. 


\section{Results}

\section{Parameters on plant growth}

The statistical analysis indicated significant effect of year as independent variable on two out of three investigated morphological characteristics such as plant height (tatarian dogwood - F $(1 ; 30)=86.032 \mathrm{p}<$ 0.001 ; cherry laurel - F $(1 ; 30)=20.388 \mathrm{p}<0.001)$ and canopy increment (tatarian dogwood $-\mathrm{F}(1 ; 30)=$ $22.354 \mathrm{p}<0.001)$. The container type effect proved to be significant on the canopy increment of tatarian $\operatorname{dogwood}(\mathrm{F}(1 ; 30)=14.858 \mathrm{p}<0.01)$, only. There was no effect on caliper increment and no interaction was observed at all.

The plant height growth showed significant higher plants for both species in 2015, while the difference of container type was significant in neither year (Table 2). The canopy increment of tatarian dogwood was larger in PIP than in CAG plants in both years with significant year effect in favour to 2016. No significant difference found in caliper increment of plants.

Table 2. Seasonal growth of different morphological parameters of tatarian dogwood and cherry laurel subjected to year and container type

\begin{tabular}{|c|c|c|c|c|c|c|c|c|c|c|c|c|}
\hline \multirow{3}{*}{$\begin{array}{c}\text { Morphological } \\
\text { parameters }\end{array}$} & \multirow{2}{*}{\multicolumn{4}{|c|}{$\frac{\text { Plant height }}{(\mathrm{cm})}$}} & \multirow{2}{*}{\multicolumn{4}{|c|}{$\begin{array}{c}\text { Canopy diameter increment } \\
(\mathrm{cm})\end{array}$}} & \multirow{2}{*}{\multicolumn{4}{|c|}{$\frac{\text { Caliper increment }}{(\mathrm{mm})}$}} \\
\hline & & & & & & & & & & & & \\
\hline & \multicolumn{2}{|c|}{$\begin{array}{c}\text { Tatarian } \\
\text { dogwood }\end{array}$} & \multicolumn{2}{|c|}{$\begin{array}{l}\text { Cherry } \\
\text { laurel }\end{array}$} & \multicolumn{2}{|c|}{$\begin{array}{c}\text { Tatarian } \\
\text { dogwood }\end{array}$} & \multicolumn{2}{|c|}{$\begin{array}{l}\text { Cherry } \\
\text { laurel }\end{array}$} & \multicolumn{2}{|c|}{$\begin{array}{c}\text { Tatarian } \\
\text { dogwood }\end{array}$} & \multicolumn{2}{|c|}{$\begin{array}{l}\text { Cherry } \\
\text { laurel }\end{array}$} \\
\hline \multicolumn{13}{|c|}{2015} \\
\hline CAG & 62.3 & $\mathrm{a}$ & 18.7 & $\mathrm{a}$ & 37.3 & $\mathrm{a}$ & 14.4 & $\mathrm{a}$ & 8.8 & $\mathrm{a}$ & 9.0 & $\mathrm{a}$ \\
\hline PIP & 64.3 & $a$ & 22.5 & $\mathrm{a}$ & 50.4 & $\mathrm{~b}$ & 13.3 & $a$ & 9.9 & $\mathrm{a}$ & 7.3 & $\mathrm{a}$ \\
\hline Mean & 63.3 & $\mathrm{~B}$ & 20.6 & $B$ & 43.9 & $\mathrm{~A}$ & 13.9 & $\mathrm{~A}$ & 9.4 & $\mathrm{~A}$ & 8.2 & A \\
\hline \multicolumn{13}{|c|}{2016} \\
\hline CAG & 17.0 & $\mathrm{a}$ & 5.7 & $\mathrm{a}$ & 54.1 & $\mathrm{a}$ & 13.3 & $\mathrm{a}$ & 7.3 & $\mathrm{a}$ & 7.8 & $\mathrm{a}$ \\
\hline PIP & 26.4 & $\mathrm{a}$ & 10.7 & $\mathrm{a}$ & 73.3 & $\mathrm{~b}$ & 18.2 & $\mathrm{a}$ & 9.3 & $\mathrm{a}$ & 6.4 & $\mathrm{a}$ \\
\hline Mean & 23.2 & $\mathrm{~A}$ & 8.2 & $\mathrm{~A}$ & 63.7 & $\mathrm{~B}$ & 15.8 & $\mathrm{~A}$ & 8.3 & $\mathrm{~A}$ & 7.1 & $\mathrm{~A}$ \\
\hline Mean & 43.3 & & 14.4 & & 53.8 & & 14.9 & & 8.9 & & 7.7 & \\
\hline
\end{tabular}

Note: CAG - container above ground, PIP - pot in pot; different letters following means discriminate within groups for each parameter at a significance level of 0.05 ; lower case - among the container types within species and year, upper case - among the years within species.

The leaf parameters were also influenced primarily by the year (individual leaf area - $\mathrm{F}(1 ; 32)=35.287$ $\mathrm{p}<0.001$; total leaf area $-\mathrm{F}(1 ; 32)=6.237 \mathrm{p}<0.05)$, but we also found strong significance on the total leaf area among the species $(\mathrm{F}(1 ; 32)=22.538 \mathrm{p}<0.001)$.

Both species developed smaller leaf size and total leaf area in 2016 than in the previous year. The species appear to have similar leaf sizes, as proven by statistics; however, the total leaf area was strongly significant. The tatarian dogwood developed near one and half time larger total leaf area compared to the cherry laurel's in both years (Table 3).

The fresh weight (FW) of root and total plant clearly show the effect of the container type also - in addition to the effect of the year. The dry weight (DW) of root and total plant is strongly influenced by the container type and interaction effect in case of tatarian dogwood; however weak significance of container type was detected for cherry laurel (Table 4). In addition, FW and DW of the leaf and shoot were tested. The container type had effect on the FW of the shoot (tatarian dogwood - F $(1 ; 16)=7.643 \mathrm{p}<0.05$; cherry laurel $-\mathrm{F}(1 ; 16)=6.728 \mathrm{p}<0.05)$ and on the DW of the shoot (tatarian dogwood $-\mathrm{F}(1 ; 16)=9.388 \mathrm{p}<0.01$; cherry laurel $-\mathrm{F}(1 ; 16)=5.935 \mathrm{p}<0.05)$ but not on the leaf parameters at all. 
Table 3. Leaf parameters of tatarian dogwood and cherry laurel subjected to year, species and container type

\begin{tabular}{|c|c|c|c|c|c|c|c|c|}
\hline \multirow{3}{*}{$\begin{array}{c}\text { Leaf } \\
\text { parameters } \\
\begin{array}{c}\text { Container } \\
\text { type }\end{array}\end{array}$} & \multirow{2}{*}{\multicolumn{4}{|c|}{$\frac{\text { Individual leaf area }}{\left(\mathrm{mm}^{2}\right)}$}} & \multirow{2}{*}{\multicolumn{4}{|c|}{$\frac{\text { Total leaf area }}{\left(\mathrm{m}^{2}\right)}$}} \\
\hline & & & & & & & & \\
\hline & \multicolumn{2}{|c|}{ Tatarian dogwood } & \multicolumn{2}{|c|}{ Cherry laurel } & \multicolumn{2}{|c|}{ Tatarian dogwood } & \multicolumn{2}{|c|}{ Cherry laurel } \\
\hline \multicolumn{9}{|c|}{2015} \\
\hline CAG & 2333.6 & $\mathrm{aA}$ & 2682.2 & $\mathrm{aB}$ & 0.69 & $\mathrm{bA}$ & 0.49 & $\mathrm{aB}$ \\
\hline PIP & 2615.0 & $\mathrm{aB}$ & 2371.6 & $\overline{a A}$ & 0.72 & $\mathrm{bA}$ & 0.40 & $\mathrm{aA}$ \\
\hline Mean & 2474.3 & & 2526.9 & & 0.70 & & 0.45 & \\
\hline \multicolumn{9}{|c|}{2016} \\
\hline CAG & 1779.6 & $\mathrm{aA}$ & 1841.5 & $\mathrm{aA}$ & 0.56 & $\mathrm{aA}$ & 0.33 & $\mathrm{aA}$ \\
\hline PIP & 1924.6 & $\mathrm{aA}$ & 2081.3 & $\mathrm{aA}$ & 0.57 & $\mathrm{bA}$ & 0.32 & $\mathrm{aA}$ \\
\hline Mean & 1852.1 & & 1961.4 & & 0.57 & & 0.33 & \\
\hline Mean & 2163.2 & & 2244.2 & & 0.64 & & 0.39 & \\
\hline
\end{tabular}

Note: CAG - container above ground, PIP - pot in pot; different letters following means discriminate within groups for each parameter at a significance level of 0.05 ; lower case - among the species within the container types and years; upper case - among the years within the species and container types; bold case - container type effect at a significance level of 0.05 .

Table 4. Outputs from the analysis of year, container type and interaction effects on the fresh (FW) - and dry weight (DW) of different plant parts

\begin{tabular}{|c|c|c|c|c|c|c|c|c|}
\hline \multirow{3}{*}{ Species } & \multicolumn{8}{|c|}{ root FW } \\
\hline & \multicolumn{4}{|c|}{ Tatarian dogwood } & \multicolumn{4}{|c|}{ Cherry laurel } \\
\hline & F-value & $d f$ & Error df & Sign. & F-value & $d f$ & Errordf & Sign. \\
\hline Year & 8.541 & 1 & 16 & $*$ & 69.444 & 1 & 16 & $* * *$ \\
\hline Container type & 8.240 & 1 & 16 & $*$ & 12.277 & 1 & 16 & ** \\
\hline \multirow[t]{2}{*}{ Year $\times$ container type } & 0.154 & 1 & 16 & ns & 0.225 & 1 & 16 & ns \\
\hline & \multicolumn{8}{|c|}{ total FW } \\
\hline Year & 6.738 & 1 & 16 & $*$ & 30.886 & 1 & 16 & $* * *$ \\
\hline Container type & 10.807 & 1 & 16 & ** & 11.405 & 1 & 16 & ** \\
\hline \multirow[t]{2}{*}{ Year $\times$ container type } & 0.117 & 1 & 16 & $\mathrm{~ns}$ & 0.039 & 1 & 16 & $\mathrm{~ns}$ \\
\hline & \multicolumn{8}{|c|}{ root DW } \\
\hline Year & 83.127 & 1 & 16 & $* * *$ & 55.069 & 1 & 16 & $* * *$ \\
\hline Container type & 49.14 & 1 & 16 & $* * *$ & 7.786 & 1 & 16 & $*$ \\
\hline \multirow[t]{2}{*}{ Year $\times$ container type } & 23.66 & 1 & 16 & $* * *$ & 0.367 & 1 & 16 & $\mathrm{~ns}$ \\
\hline & \multicolumn{8}{|c|}{ total DW } \\
\hline Year & 64.965 & 1 & 16 & $* * *$ & 23.479 & 1 & 16 & *** \\
\hline Container type & 47.165 & 1 & 16 & $* * *$ & 7.360 & 1 & 16 & $*$ \\
\hline Year $\times$ container type & 18.317 & 1 & 16 & $* *$ & 0.059 & 1 & 16 & ns \\
\hline
\end{tabular}

Note: Table shows F-values and the corresponding level of significance (Sign.); ns - not significant, ${ }^{*}-\mathrm{p}<0.05,{ }^{* *}-\mathrm{p}<$ $0.01,{ }^{* * *}-\mathrm{p}<0.001$.

Each characteristic - except for the leaf - are significantly higher in PIP cultivated tatarian dogwood, whereas the same difference was found in CAG grown cherry laurel (Table 5). 
Table 5. Fresh (FW) and dry weight (DW) of plant parts of tatarian dogwood and cherry laurel subjected container type (CAG and PIP) in 2015 and 2016

\begin{tabular}{|c|c|c|c|c|c|c|c|c|}
\hline & \multicolumn{4}{|c|}{ leaf FW g plant ${ }^{-1}$} & \multicolumn{4}{|c|}{ leaf DW g plant ${ }^{-1}$} \\
\hline Species & \multicolumn{2}{|l|}{ Tatarian dogwood } & \multicolumn{2}{|l|}{ Cherry laurel } & \multicolumn{2}{|c|}{ Tatarian dogwood } & \multicolumn{2}{|c|}{ Cherry laurel } \\
\hline \multicolumn{9}{|c|}{2015} \\
\hline CAG & 109.3 & $\mathrm{a}$ & 180.8 & $\mathrm{a}$ & 40.7 & $\mathrm{a}$ & 62.8 & $\mathrm{a}$ \\
\hline PIP & 120.8 & $\mathrm{a}$ & 135.7 & $\mathrm{a}$ & 42.7 & a & 46.1 & $\mathrm{a}$ \\
\hline \multicolumn{9}{|c|}{2016} \\
\hline CAG & 77.0 & $\mathrm{a}$ & 130.9 & $\mathrm{a}$ & 29.7 & $\mathrm{a}$ & 49.7 & $\mathrm{a}$ \\
\hline PIP & 103.3 & $\mathrm{a}$ & 126.8 & $\mathrm{a}$ & 42.3 & $a$ & 49.7 & $\mathrm{a}$ \\
\hline & \multicolumn{4}{|c|}{ shoot FW g plant ${ }^{-1}$} & \multicolumn{4}{|c|}{ shoot DW g plant ${ }^{-1}$} \\
\hline \multicolumn{9}{|c|}{2015} \\
\hline CAG & 122.6 & $\mathrm{a}$ & 165.5 & $\mathrm{~b}$ & 57.4 & $\mathrm{a}$ & 63.9 & $\mathrm{~b}$ \\
\hline PIP & 170.2 & $\mathrm{~b}$ & 116.7 & $\mathrm{a}$ & 79.0 & $\mathrm{~b}$ & 44.8 & $a$ \\
\hline \multicolumn{9}{|c|}{2016} \\
\hline CAG & 151.8 & $\mathrm{a}$ & 115.4 & $\mathrm{~b}$ & 73.2 & $\mathrm{a}$ & 50.0 & $\mathrm{~b}$ \\
\hline PIP & 182.6 & $\mathrm{~b}$ & 108.4 & $\mathrm{a}$ & 92.8 & $\mathrm{~b}$ & 48.3 & $\mathrm{a}$ \\
\hline & \multicolumn{4}{|c|}{ root FW g plant ${ }^{-1}$} & \multicolumn{4}{|c|}{ root DW g plant ${ }^{-1}$} \\
\hline \multicolumn{9}{|c|}{2015} \\
\hline CAG & 546.6 & $\mathrm{a}$ & 414.0 & $\mathrm{~b}$ & 114.3 & $\mathrm{a}$ & 111.6 & $\mathrm{~b}$ \\
\hline PIP & 735.4 & $\mathrm{~b}$ & 243.0 & $\mathrm{a}$ & 171.3 & $\mathrm{~b}$ & 72.6 & $\mathrm{a}$ \\
\hline \multicolumn{9}{|c|}{2016} \\
\hline CAG & 739.4 & $\mathrm{a}$ & 911.1 & $\mathrm{~b}$ & 227.2 & $\mathrm{a}$ & 254.9 & $\mathrm{~b}$ \\
\hline PIP & 987.9 & $\mathrm{~b}$ & 686.6 & $\mathrm{a}$ & 542.3 & $\mathrm{~b}$ & 194.3 & $\mathrm{a}$ \\
\hline & \multicolumn{4}{|c|}{ total FW g plant ${ }^{-1}$} & \multicolumn{4}{|c|}{ total DW g plant ${ }^{-1}$} \\
\hline \multicolumn{9}{|c|}{2015} \\
\hline CAG & 778.5 & $\mathrm{a}$ & 760.3 & $\mathrm{~b}$ & 212.4 & $\mathrm{a}$ & 238.3 & $\mathrm{~b}$ \\
\hline PIP & 1026.4 & $\mathrm{~b}$ & 495.5 & $\mathrm{a}$ & 293.0 & $\mathrm{~b}$ & 163.5 & $\mathrm{a}$ \\
\hline \multicolumn{9}{|c|}{2016} \\
\hline CAG & 968.2 & $\mathrm{a}$ & 1157.4 & $\mathrm{~b}$ & 330.1 & $\mathrm{a}$ & 354.6 & $\mathrm{~b}$ \\
\hline PIP & 1273.8 & $\mathrm{~b}$ & 921.8 & $a$ & 677.3 & $\mathrm{~b}$ & 292.2 & $\mathrm{a}$ \\
\hline
\end{tabular}

Note: CAG - container above ground, PIP - pot in pot; different letters following means discriminate among the container types within species and year for each parameter at a significance level of 0.05 .

\section{Performance of water use of container grown plants}

Gravimetric measured daily water use

Water use data shows that the plant species and the sampling day essentially determined the performance of daily water use (DWU) in both years. The initial container weight (IWC) as another independent variable was influenced also by the species and sampling day. Container type effects were also observed in almost all cases (Table 6). 
Table 6. Outputs from the analysis of species, container type, sampling day and interaction effects on the initial weight of container (IWC) and daily water use of container (DWU)

\begin{tabular}{|c|c|c|c|c|c|c|c|c|}
\hline & \multicolumn{4}{|c|}{ IWC } & \multicolumn{4}{|c|}{ DWU } \\
\hline 2015 & F-value & $d f$ & Error $d f$ & Sign. & F-value & $d f$ & Error df & Sign. \\
\hline Species & 262.990 & 1 & 105 & *** & 261.577 & 1 & 106 & *** \\
\hline Container type & 61.197 & 1 & 105 & *** & 0.435 & 1 & 106 & ns \\
\hline Sampling day & 78.123 & 2 & 105 & *** & 22.416 & 2 & 106 & *** \\
\hline Container type $\times$ species & 12.960 & 1 & 105 & *** & 7.259 & 1 & 106 & ** \\
\hline Container type $\times$ sampling day & 47.328 & 2 & 105 & *** & 40.256 & 2 & 106 & $* * *$ \\
\hline Species $\times$ sampling day & 2.094 & 2 & 105 & $\mathrm{~ns}$ & 0.220 & 2 & 106 & $\mathrm{~ns}$ \\
\hline Container type $\times$ species $\times$ sampling day & 0.334 & 2 & 105 & ns & 0.916 & 2 & 106 & ns \\
\hline 2016 & F-value & $d f$ & Error $d f$ & Sign. & F-value & $d f$ & Errordf & Sign. \\
\hline Species & 193.689 & 1 & 97 & *** & 126.018 & 1 & 96 & *** \\
\hline Container type & 107.276 & 1 & 97 & *** & 19.316 & 1 & 96 & *** \\
\hline Sampling day & 128.711 & 2 & 97 & *** & 32.431 & 2 & 96 & *** \\
\hline Container type $\times$ species & 1.226 & 1 & 97 & ns & 9.397 & 1 & 96 & ** \\
\hline Container type $\times$ sampling day & 2.705 & 2 & 97 & ns & 72.215 & 2 & 96 & *** \\
\hline Species $\times$ sampling day & 18.074 & 2 & 97 & *** & 5.575 & 2 & 96 & ** \\
\hline Container type $\times$ species $\times$ sampling day & 6.176 & 2 & 97 & ** & 0.653 & 2 & 96 & $\mathrm{~ns}$ \\
\hline
\end{tabular}

The IWC of the species differed significantly in both years. The IWC of the cherry laurel was heavier, typically. Container weight of each sampling day is well separated within a given species and year and is usually divided into two groups. The effect of the container type is strongly prevailed in the case of cherry laurel, whereas the IWC is significant higher in PIP, on each sampling day. IWC of tatarian dogwood tends to be higher in PIP than in CAG, in both years, but statistically significant in 2016.

The mean DWU of tatarian dogwood ranged between 454-747 $\mathrm{g} \mathrm{day}^{-1}$, in 2015. The significant lower DWU was measured on 05 June. DWU of cherry laurel ranged between 255-390 $\mathrm{g} \mathrm{day}^{-1}$ in the same year, where the lowest value was measured on 22 September. Container type effect was not detected in 2015. Tatarian dogwood showed 206-474 $\mathrm{g} \mathrm{day}^{-1} \mathrm{DWU}$, in 2016. Sampling days are statistically divided into two groups, where we found on the sampling day of midsummer (05 July) the lowest DWU. Container type effect is clearly seen for this species. The mean DWU of cherry laurel was between 219-274 $\mathrm{g} \mathrm{day}^{-1}$ in 2016. Container type effect was not detected, however, PIP grown plants had steadier DWU than CAG plants (Table 7). 
Table 7. Variation in initial weight of container (IWC g container ${ }^{-1}$ ) and daily water use of container $\left(\mathrm{DWU} \mathrm{g} \mathrm{day}^{-1}\right.$ ) subjected to species, sampling day and container type (CAG and PIP) in 2015 and 2016

\begin{tabular}{|l|c|c|c|c|c|c|c|c|c|c|c|c|c|c|}
\hline \multicolumn{10}{|c|}{ IWC $(\mathrm{g}$ container } \\
\hline
\end{tabular}

Note: CAG - container above ground, PIP - pot in pot; different letters following means discriminate within groups for each parameter at a significance level of 0.05 ; lower case - among the species within the container types and years; upper case - among the days within the species; bold case - container type effect at a significance level of 0.05 .

\section{Transpiration based method}

The total daily transpiration (DT) was primarily influenced by the sampling days, but the species also showed significant differences. The type of container had no effect on the DT, but its interaction with the sampling day was significant (Table 8).

Table 8. Outputs from the analysis of species, container type, sampling day and interaction effects on the total daily transpiration (DT)

\begin{tabular}{|l|c|c|c|c|}
\hline & \multicolumn{3}{|c|}{ DT } & Sign. \\
\hline Species & F-value & $d f$ & Errordf & ${ }^{*}$ \\
\hline Container type & 6.731 & 1 & 191 & ns \\
\hline Sampling day & 0.006 & 1 & 191 & ${ }^{* * *}$ \\
\hline Species $\times$ container type & 22.497 & 5 & 191 & ns \\
\hline Species $\times$ sampling day & 0.020 & 1 & 191 & ${ }^{* * *}$ \\
\hline Container type $\times$ sampling day & 50.404 & 5 & 191 & ${ }^{* *}$ \\
\hline Species $\times$ container type $\times$ sampling day & 3.962 & 5 & 191 & ns \\
\hline
\end{tabular}

Note: Table shows F-values and the corresponding level of significance (Sign.); ns - not significant, ${ }^{*}-\mathrm{p}<0.05,{ }^{* *}-\mathrm{p}<$ $0.01,{ }^{* * *}-\mathrm{p}<0.001$.

According to data, the DT of tatarian dogwood leaf surface was between $0.88-1.56 \mathrm{~kg} \mathrm{~m}^{-2}$, which reached its peak on 22 September, in the year of 2015 (Tukey, $\mathrm{p}<0.05$ ). The stomatal conductance also shows that the sampling day of September had the lowest stomatal resistance, which is expressed by the higher value of stomatal conductance (Figure 3). Sampling days of summer, the plants transpired clearly less (Tukey, p $<0.05$ ), with steady stomatal conductance. The DT of cherry laurel varied between 0.80 and $1.19 \mathrm{~kg} \mathrm{~m}^{-2}$, in 2015. The 
DT of summer sampling days was higher (Tukey, $\mathrm{p}<0.05$ ) than in September. In contrast, stomatal conductance showed almost the same value regardless to the season.

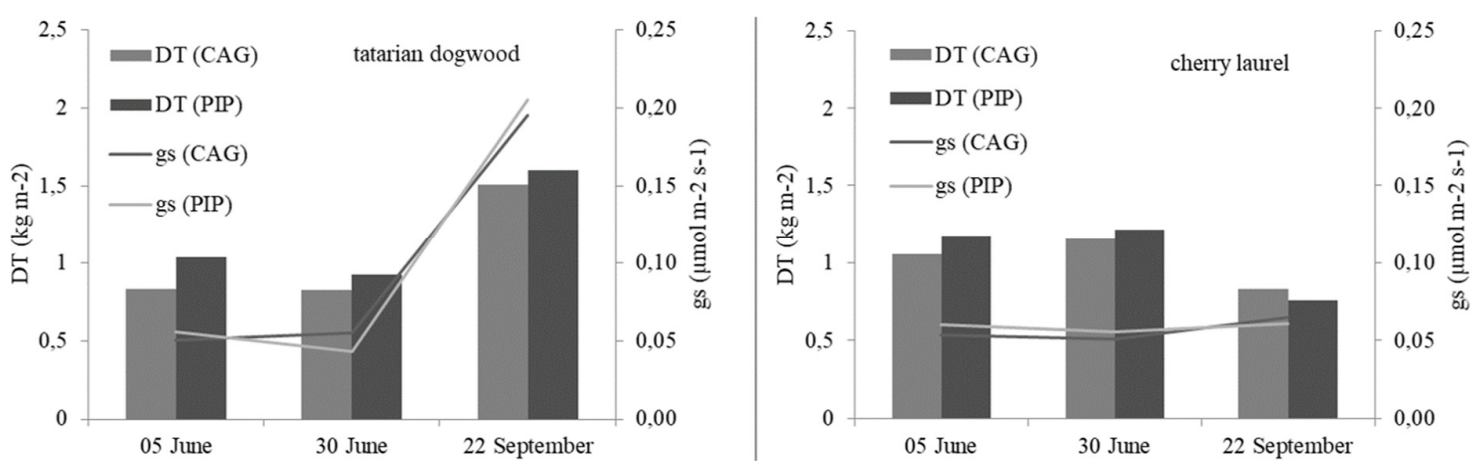

Figure 3. Total daily transpiration (DT) and stomatal conductance (gs) on the sampling days in 2015 of container grown (CAG; PIP) tatarian dogwood and cherry laurel (Páty, Hungary)

The repeated measurement in 2016 showed that tatarian dogwood transpired $0.75-1.88 \mathrm{~kg} \mathrm{~m}^{-2}$ per day. DT was high at the beginning of summer (07 June) and early autumn (16 September). DT was significantly the lowest on another summer sampling day (05 July) (Tukey, $\mathrm{p}<0.05)$. The stomatal conductance was much lower on this day (stomas were mostly closed) compared to other sampling days. The DT of cherry laurel varied between $0.97-1.56 \mathrm{~kg} \mathrm{~m}^{-2}$, in 2016. The highest DT was observed in the middle of summer (05 July) (Tukey, $\mathrm{p}$ $<0.05$ ). The stomatal conductance showed a slight increase in chronological order (Figure 4.)
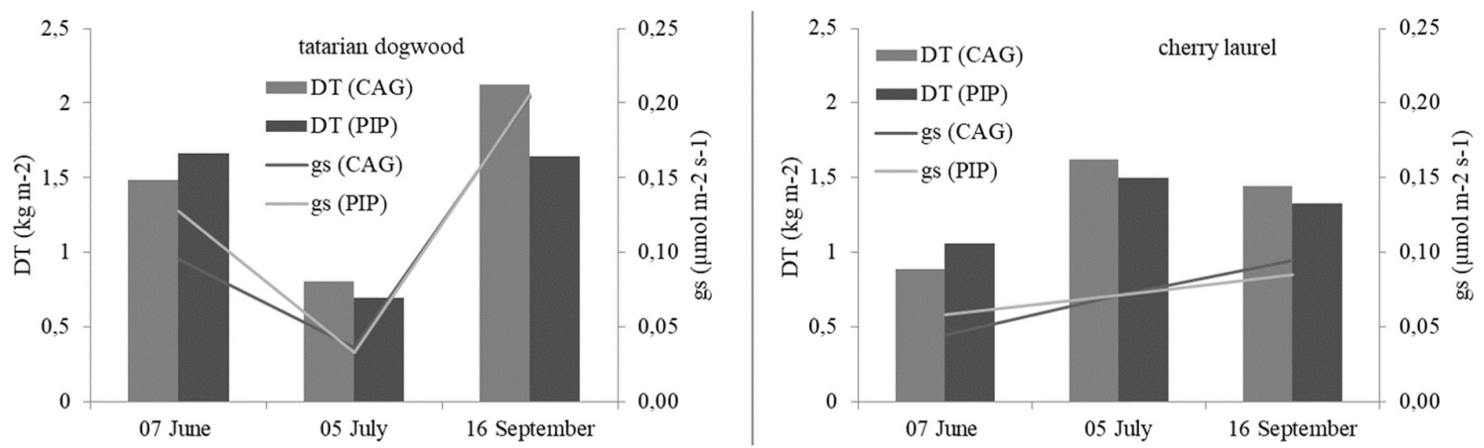

Figure 4. Total daily transpiration (DT) and stomatal conductance (gs) on the sampling days in 2016 of container grown (CAG; PIP) tatarian dogwood and cherry laurel (Páty, Hungary)

\section{Discussion}

\section{Annual weather conditions}

Years in which the experiments were carried out showed differences mainly regarding the amount of precipitation and the distribution of it, both on yearly basis and growing seasonal basis. Summarising the results, the yearly amount of precipitation in 2015 was slightly below the yearly average of the country, however, it was one of the warmest years in the past 100 years (Climate retrospective, 2015). Based on the data of the local meteorological station (Figure 2), the potential evapotranspiration exceeded the total amount of precipitation with more than $100 \mathrm{~mm}$, on a yearly basis, and in the growing season this difference was even higher, $175 \mathrm{~mm}$. The local yearly average temperature $\left(11.90^{\circ} \mathrm{C}\right)$ was higher than the country average $(11.72$ 
$\left.{ }^{\circ} \mathrm{C}\right)$. So, in the country it was a dry unusually warm year, which was further enhanced by the local climatic conditions. Contrary to the above, in 2016 , the yearly country average temperature $\left(11.13^{\circ} \mathrm{C}\right)$ was lower than in 2015 , but the local average temperature $\left(11.19^{\circ} \mathrm{C}\right)$ was similar to the country average. According to the yearly amount of precipitation in the country, this year is to be considered as more than average wet, with record amount of rain in July, which significantly increased the local amount of precipitation $(\sim 100 \mathrm{~mm})$ in the growing season, compared to the previous year (Climate retrospective, 2016). Locally, the yearly amount of precipitation, differently to the previous year, significantly exceeded the value of the potential evapotranspiration $(\sim 200 \mathrm{~mm})$, however, this difference became balanced regarding the growing season ( 20 $\mathrm{mm})$.

\section{Sampling days weather conditions}

The first test days in each year were greatly different. The average daily air temperature was $21.17^{\circ} \mathrm{C}$, with $28.20^{\circ} \mathrm{C}$ daily maximum on the 05 June in 2015 . Temperature exceeded the typical average temperature of the month, moreover daily maximum temperature was above $30{ }^{\circ} \mathrm{C}$ during the previous week, with no precipitation. Test day of the following year, was chosen from a same period as in 2015, however, on the 07 June in 2016, was cooler than it typical for June, and more than $30 \mathrm{~mm}$ of precipitation has fallen over the previous week. The daily maximum did not exceed $25^{\circ} \mathrm{C}$ and the lowest humidity was shown among the measurement days (47.67\%). The next test day was on the 30 June in 2015. During the preceding week, the mean daily temperature increased steadily, but the daily maximum temperature remained below $30^{\circ} \mathrm{C}$. In 2016 , on the 05 July, the daily maximum exceeded $30^{\circ} \mathrm{C}$. The average daily air temperature was $22.11{ }^{\circ} \mathrm{C}$. Two extremely hot (average daily temperature was above $25^{\circ} \mathrm{C}$ ) and dry weeks preceded that test day. The last two measure day of each year both were carried out in September. In 2015, on 22 September (2015) the daily maximum temperature exceeded the average daily maximum of the month, but the daily minimum was below (with $4-5$ degrees) the long-term average, so the average daily temperature $\left(14.67^{\circ} \mathrm{C}\right)$ was low during this time of year. The final test day on 16 September showed high daily average temperature $\left(22.31^{\circ} \mathrm{C}\right)$. The daily maximum temperature on that day, was closest to the temperatures of summer test days $\left(28.63{ }^{\circ} \mathrm{C}\right)$, but the average relative humidity was the highest on that day, compared to the other measurement days (67.51\%).

\section{Parameters on plant growth}

The plant growth characteristics showed typical performance to tatarian dogwood 'Sibirica', the crown was wider than taller like at older ages (Tóth, 2012). Considering the container types, the canopy diameter was larger in the PIP grown plants in both years than in the CAG, however, the height and caliper diameter of the plants were not affected by the container type. According to the literature (Tóth, 2012) cherry laurel 'Novita' is a fast-growing variety but our results in young nursery stage do not confirm this opinion. Numerical data are not available; however, based on the low growth rate related to the tatarian dogwood, we assume that cherry laurel is below the growth characteristics of the species. The effect of the container type was not verified for any of the parameters. The total leaf area of the tatarian dogwood is significantly larger on PIP grown plants, almost one and a half times larger than that of the cherry laurel, while CAG plants showed similar tendency. The fresh and dry weight of the plant parts show more clearly the difference in container types compared to the other morphological parameters. The different behaviour of the species is also evident, as PIP cultivation results in more favourable values for tatarian dogwood, whereas cherry laurel developed better in the CAG. Our results underline that the nursery performance the two species (dogwood and cherry laurel) differ from the adult stage characters described by Tóth (2012).

Our results are in line with the results of other authors, as they showed different performance of species in different container types. Ruter (1993) could not prove the impact of the container type on plant height of CAG grown and PIP grown Ilex $\times$ attenuata Ashe 'Savannah', and Magnolia $\times$ soulangiana Soul.-Bod., however, for the latter, the branch system developed better in PIP. In contrary, the same author detected that Lagerstroemia indica $\times$ fauriei 'Natchez' were taller in CAG than in PIP. The shoot dry weight was not affected 
by container type none of the species but larger root dry weight and plant biomass were detected for $M . \times$ soulangiana and higher dry weight for $L$. indica $\times$ fauriei in PIP. In another study, the shoot and root dry weight of the crape myrtle was smaller in CAG than in PIP, after two months (Schluckebier and Martin, 1997). According to (Miralles et al., 2009), the plant height of the Myrtus communis increased with $16 \%$ in the CAG, and developed higher shoot dry weight, while the root dry weight was higher in the PIP. Regarding the plant height of Rhamnus alternus L. no difference was detected between the container types, but the root dry weight was strongly significant in the PIP (Miralles et al., 2012). The results so far show that the effect of the PIP container type on plant characteristics is not consistent. Our own result is more obvious, as all plant parts of tatarian dogwood - except leaf - had higher fresh - and dry weight in PIP. In contrary, all parts of cherry laurel except leaf - had larger fresh and dry weight in CAG.

\section{Performance of water use of container grown plants}

The IWC of container grown plants involve the weight of container (constant), substrate and the plant thus strongly depends on the water content of the rootball substrate - plant complex system. The IWC of tatarian dogwood containers was $81 \%$ in 2015 and $80 \%$ in 2016, significant lower compared to cherry laurel (Table 7). This suggests that this last species started the sampling day at higher water reserve in the rootball substrate and in the plant. We found significant higher IWC of PIP plants for cherry laurel in 2015 and for both species in 2016, except for the hot day on 05 July in 2016 for tatarian dogwood. These data confirm the advantage of PIP system shown by other authors (Schluckebier and Martin, 1997; Ruter, 1998a; 1998b) in more efficient water management which provide higher water supply capacity in the morning of sampling days. The source of this higher water capacity are the water left over from previous days, the previous day's irrigation (constant) and the retained water over the night. The significant lower IWC of tatarian dogwood plants on 05 July (Table 7) indicate that the previous days irrigation was not sufficient to compensate the higher water loss during the hot period in early July 2016.

The DWU of the two container grown species showed large differences. Our data are more or less in line to those found in the literature, which show species-specific tendency and container size effect. Albeit both species are characterized as moderate water requiring plants (Tóth, 2012), we found large differences in DWU. The tatarian dogwood as average of the three sampling days used $626 \mathrm{~g} \mathrm{day}^{-1}$ water (194\%) compared to the cherry laurel's $341 \mathrm{~g} \mathrm{day}^{-1}$ water use in 2015, while in 2016 this ratio was $144 \%$ in favor of tatarian dogwood (Table 6). These large differences in DWU of the two plant species might be caused partly by the total leaf area differences (156\% and 164\% for tatarian dogwood in relation to cherry laurel in 2015 and 2016 respectively). The DWU of cherry laurel was more balanced in both years while the tatarian dogwood showed larger fluctuations. In 2015 the first sampling day's DWU of tatarian dogwood was significantly lower, which could be explained by the smaller initial plant size. On 05 July in 2016, probably the extremely hot day and the insufficient water supply (morning weight of containers was 78\% for CAG and 57\% for PIP compared to the previous sampling day) reduced the DWU. The correlation between IWC and the DWU of tatarian dogwood plants support this idea (Figure 5). The container type affected the DWU for the first and the third sampling day of tatarian dogwood in 2016. Our results on DWU are more or less similar to those found by former study (O'Meara et al., 2013) on the DWU of Hydrangea macrophylla 'Fasan' and Gardenia jasminoides 'Radicans' which ranged 50-200- and 50-560- $\mathrm{mL}$ plant $^{-1}$ day $^{-1}$ in a $6 \mathrm{~L}$ volume container, respectively. Similar DWU reported in another study on oak leaf hydrangea (Hydrangea quercifolia 'Alice') grown in $11.4 \mathrm{~L}$ containers:

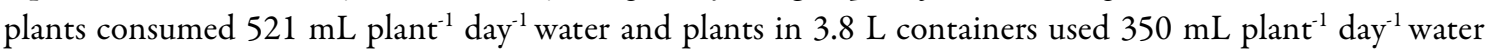
(Hagena et al., 2014). García-Navarro et al. (2004) also determined water use of four container-grown cultivars of Spiraea $x$ vanhouteii and Viburnum tinus. Both species grew in $3.8 \mathrm{~L}$ containers. The experiment resulted 1.5-4.5 L day ${ }^{-1}$ water use per plant for Spirea and 0.5-2 $\mathrm{L} \mathrm{day}^{-1}$ for Viburnum. Our results underline that the nursery performance the two species in daily water use differ from the water demand of plants in adult stage characterized by Tóth (2012). 
Our data seem to be useful for planning the irrigation in practice. Further practical consequence should be considered: due to the large species-specific water use the dogwood and cherry laurel should be placed in different irrigation blocks. Considering the irrigation dosage of the nursery $\left(200 \mathrm{~g} \mathrm{day}^{-1}\right.$ water for each containers) we can state that the water amount given by the irrigation system was far low for the requirements of tatarian dogwood and slightly low for cherry laurel.

\section{Total daily transpiration of container-grown plants}

The mean of the two year's DT were $1.17 \mathrm{~kg} \mathrm{~m}^{-2}$ for cherry laurel and $1.26 \mathrm{~kg} \mathrm{~m}^{-2}$ for tatarian dogwood. Calculating with the mean final leaf area (for cherry laurel $0.42 \mathrm{~m}^{2}$ and that of tatarian dogwood $0.67 \mathrm{~m}^{2}$, Table 3) the transpiration part of the DWU would make $490 \mathrm{~g}$ and $840 \mathrm{~g}$ respectively, which is higher than the measured DWU. This means, our transpiration measurements overestimated the real transpiration. The reason might be in the selected leaves: sunlit, well developed leaves were investigated, the lower transpiration activity of shade and small leaves were not considered. Nevertheless, the performance of transpiration of leaves may characterize the main tendencies.

The DT of each sampling day differed significantly between species, however the performance of DT on different sampling days was inconsistent. Cherry laurel had higher DT typically on summer sampling days, while on autumn sampling days the tatarian dogwood transpired more. There was on exeption when tatarian dogwood had higher DT than cherry laurel during summer time; on the 07 June in 2016 was cooler than it typical for June, in addition, more than $30 \mathrm{~mm}$ of precipitation has fallen over the previous week. At this time, the daily maximum did not exceed $25^{\circ} \mathrm{C}$ and the lowest humidity was shown among the measurement days (47.67\%). According to this, it is a species response to the weather conditions of the sampling days. This is well illustrated by the fact that while stomatal conductance of tatarian dogwood changes with DT, cherry laurel's stomatal conductance is less responsive to environmental change (Figures 3, 4). In a previous study, Prunus laurocersus L. was shown to be more adaptable to environmental stress than changes in the deciduous Ginkgo biloba L. or Juglans regia L. (Kirsh et al., 1997). Our conclusion is that the DT of the deciduous tatarian dogwood responses more sensitive to environmental conditions than the evergreen cherry laurel. As the LCi measured transpiration was modelled by projecting the instantaneous transpiration value of sunlit, well developed leaves but not the whole canopy, we concluded that this measurements overestimate the gravimetric measured DWU. Despite the heterogeneity of the canopy, it gives a good approximation of species differences, since it covers the gravimetric measured tendencies.

\section{Conclusions}

The daily water use of container grown nursery plants of tatarian dogwood and cherry laurel showed large differences $194 \%$ to $144 \%$ in favor of tatarian dogwood. Considering the DT values our conclusion is that the DT of the deciduous tatarian dogwood responses more sensitive to environmental conditions than the evergreen cherry laurel. The higher IWC values of PIP grown plants suggest higher water capacity of plants and rootball substrate which results in better water supply. The container type affected the plant morphology; however, the container type effect is amplified by the species character and the seasonality. The tatarian dogwood only showed improved quality in the PIP system (enhanced canopy increment, fresh and dry weight).

\section{Acknowledgements}

This research was supported by the Ministry for Innovation and Technology within the framework of the Higher Education Institutional Excellence Program (NKFIH-1159-6/2019) in the scope of plant breeding and plant protection researches of Szent István University. 


\section{Conflict of Interests}

The authors declare that there are no conflicts of interest related to this article.

\section{References}

Beeson RC (2004). Modelling actual evapotranspiration of Ligustrum japonicum from rooted cuttings to commercially marketable plants in 12 liter black polyethylene containers. Acta Horticulturae 664:71-77. https://doi.org/10.17660/ActaHortic.2004.664.6

Beeson RC (2005). Modelling irrigation requirements for landscape ornamentals. HortTechnology 15:18-22. https://doi.org/10.21273/HORTTECH.15.1.0018

Beeson RC (2006). Relationship of plant growth and actual evapotranspiration to irrigation frequency based on management allowed deficits for container nursery stock. Journal of the American Society for Horticultural Science 131:140-148. https://doi.org/10.21273/JASHS.131.1.140

Beeson R, Chen J (2018). Quantification of daily water requirements of container-grown calathea and stromanthe produced in a shaded greenhouse. Water 10:1194. https://doi.org/10.3390/w10091194

Chabin J (2015). Personal communication (Jaroslaw Chabin Tree Nursery owner)

Climate retrospective (2015). 2015 summer weather (in Hungarian). https://www.met.hu/omsz/OMSZ_hirek/index.php?id=1453

Climate retrospective (2016). 2016 summer weather (in Hungarian). https://www.met.hu/omsz/OMSZ_hirek/index.php?id=173

Garcia-Navarro MC, Evans RY, Savé R, (2004). Estimation of relative water use among ornamental landscape species. Scientia Horticulturae 99(2):163-174.

Grant OM, Davies MJ, Longbottom H, Harrison-Murray R (2010). Evapotranspiration of container ornamental shrubs: modelling crop-specific factors for a diverse range of crops. Irrigation Science 30(1):1-12.

Hagena ES, Nambuthiri, Fulcher A, Geneve R (2014). Comparing substrate moisture-based daily water use and ondemand irrigation regimes for oakleaf hydrangea grown in two container sizes. Scientia Horticulturae 179:132139.

Ingram DL, Ruter JM, Martin CA (2015). Review: characterization and impact of supraoptimal root-zone temperatures in container-grown plants. HortScience 50:530-539.

Kirsch T, Kaffarnik F, Riederer M, Schreiber L (1997). Cuticular permeability of the three tree species Prunus laurocerasus L., Ginkgo biloba L. and Juglans regia L.: comparative investigation of the transport properties of intact leaves, isolated cuticles and reconstituted cuticular waxes. Journal of Experimental Botany 48(310):1035-1045.

MDSZ (2014). A Magyar Díszkertészet Ágazati Stratégiája [Sectoral strategy of the Hungarian ornamental horticulture]. https://www.diszkerteszek.hu/ma_files/MDSZ_strategia.pdf

Majsztrik JC, Ristvey AG, Lea-Cox JD (2011). Water and nutrient management in the production of container-grown ornamentals. Horticultural Reviews 38:253-297.

Majsztrik JC, Fernandez RT, Fisher PR, Hitchcock DR, Lea-Cox J, Owen JS, ... White SA (2017). Water use and treatment in container-grown specialty crop production: A Review. Water, Air and Soil Pollution 228:151. https://doi.org/10.1007/s11270-017-3272-1

Martin CA, McDowell LB, Bhattacharya S (1999). Below ground pot-in-pot effects on growth of two southwest landscape trees was related to root membrane thermostability. Journal of Environmental Horticulture 17:636-638.

Miralles J, Nortes Tortosa PA, Sánchez-Blanco MJ, Martínez-Sánchez JJ, Bañón AS (2009). Above-ground and pot-inpot production systems for Myrtus communis L. https://elibrary.asabe.org/abstract.asp?aid=25950

Miralles J, Martínez-Sánchez JJ, Bañón S (2012). The "pot-in-pot" system enhances the water stress tolerance compared with above-ground pot. Ismail $\mathrm{Md}$ et al. (Eds). Water Stress. IntechOpen, https://www.intechopen.com/books/water-stress/the-pot-in-pot-system-enhances-the-water-stress-tolerancecompared-with-above-ground-pot. 
Miralles J, Franco JA, Sánchez-Blanco MJ, Bañón S (2016). Effects of pot-in-pot production system on water consumption, stem diameter variations and photochemical efficiency of spindle tree irrigated with saline water. Agricultural Water Management 170:167-175.

Newman JP (2014). Container nursery production and business management manual. UCANR Publications, pp 5-6.

Niu G, Rodriguez DS, Cabrera R, McKenney C, Mackay W (2006). Determining water use and crop coefficients of five woody landscape plants. Journal of Environmental Horticulture 24:160-165.

O'Meara L, van Iersell MW, Chappell MR, (2013). Modelling daily water use of Hydrangea macrophylla and Gardenia jasminoides as affected by environmental conditions. Hortscience 48(8):1040-1046.

Ruter JM (1993). Growth and landscape performance of three landscape plants produced in conventional and pot-in-pot production systems. Journal of Environmental Horticulturae 11:124-127.

Ruter JM (1998a). Fertilizer rate and pot-in-pot production increase growth of heritage river birch. Journal of Environmental Horticulturae 16:135-138.

Ruter JM (1998b). Pot-in-pot production and cyclic irrigation influence growth and irrigation efficiency of "Okame" cherries. Journal of Environmental Horticulturae 16:159-162.

Schluckebier JG, Martin CA (1997). Effects of above-ground pot-in-pot (PIP) placement and humic acid extract on growth of crape myrtle. Journal of Environmental Horticulturae 15:41-44. https://doi.org/10.24266/0738-289815.1.41

Tóth I (2012). Lomblevelű díszfák, díszcserjék kézikönyve [Handbook of broad-leaved ornamental trees and shrubs], Tarkavirág Kereskedelmi és Szolgáltató Kft., Budapest.
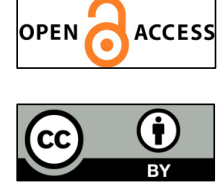

The journal offers free, immediate, and unrestricted access to peer-reviewed research and scholarly work. Users are allowed to read, download, copy, distribute, print, search, or link to the full texts of the articles, or use them for any other lawful purpose, without asking prior permission from the publisher or the author.

License - Articles published in Notulae Botanicae Horti Agrobotanici Cluj-Napoca are Open-Access, distributed under the terms and conditions of the Creative Commons Attribution (CC BY 4.0) License. (c) Articles by the authors; UASVM, Cluj-Napoca, Romania. The journal allows the author(s) to hold the copyright/to retain publishing rights without restriction. 